\title{
Estimation of Groundwater Recharge by Water Budget Method in Conjunction with Water Table Fluctuation Method, Munger district, Bihar
}

\author{
Md Nawid Ashraf ${ }^{1 *}$, Alex Thomas ${ }^{1}$, Md Tahsin Ashraf ${ }^{2}$ and Pankaj Kumar ${ }^{1}$ \\ ${ }^{1}$ Department of Soil and Water Conservation Engineering, Vaugh Institute of Agricultural \\ Engineering and Technology, Sam Higginbottom University of Agriculture Technology and \\ Sciences, Prayagraj- 211007 (U.P), India \\ ${ }^{2}$ Department of Farm Machinery and Power Engineering, IGkV, Raipur (C.G.), India \\ *Corresponding author
}

\section{A B S T R A C T}

\section{Keywords}

Water table, surplus of groundwater,

Water Table

Fluctuation,

Evapotranspiration

Article Info

Accepted:

15 June 2021

Available Online:

10 July 2021
Estimation of groundwater is an effective tool for proper planned and optimal utilization of water resources in the context of future requirement. Our main purpose for the estimation of groundwater in Munger district is to make a complete assessment of groundwater resources and produce information that can be incorporated for future requirement. The study was undertaken based on the recommendation of groundwater estimation committee, 1997 (GEC-97). Methodology used the estimation of annual groundwater recharge from rainfall and other sources including irrigation, water bodies and artificial recharge, determination of present status of groundwater utilization and categorization of assessment units based on the level of groundwater utilization and long- term water level trend. Water level fluctuation techniques and empirical norms were used for recharge estimation. The data collected for investigation were water table fluctuation, rainfall, cropping pattern, number of groundwater structures, geographical area, groundwater draft, ponds area etc. The study reveals that for Munger district the total annual groundwater recharge is 37434.63 ha- $\mathrm{m}$, the net annual groundwater draft for all uses is $8968 \mathrm{ha}-\mathrm{m}$, the net groundwater available for future irrigation development is 21097 ha-m. The stage of groundwater development is $33.3 \%$ for Munger district which fall in safe categories for district. The surplus of groundwater available for future agriculture is $8091 \mathrm{ha}-\mathrm{m}$ and the additional energy requirement for abstraction of surplus of groundwater available for future agriculture is $4.4 \times 10^{6} \mathrm{KWh}$ for Munger district.

\section{Introduction}

Groundwater plays an important role in the environment. It restores streams, rivers and wetlands and helps support a living environment. It is used as a primary source of drinking water and for agricultural and industrial purposes. Rainwater is a major source of agricultural water but groundwater, which is 38.5 percent of the country's available resources, plays a major role in supplying drinking water, both in rural and 
urban areas and in industrial development. Globally, groundwater resources are under increasing pressure due to intensified human activity and other factors such as climate change. The main cause of over-exploitation of groundwater is the growing demand from agriculture and the rapid urban and industrial growth. In many groundwater areas, decisions on planting pattern and crop stability are largely taken without the availability of groundwater.

Water-intensive crops have therefore been inclined to grow in the face of water shortages. Excessive exploitation of groundwater leads to: reduced water production in wells, increased pumping depth and pumping costs, groundwater pollution due to geogenic factors, leading to increased fluoride, arsenic, iron levels and most importantly, resource failure leading to severe economic losses. Excessive exploitation of resources at work in many parts of the country has led to the rapid descent of the groundwater table. This has not only threatened food and environmental security, but also sustainable development. The depletion of groundwater resources has had a profound effect on small and medium-sized farmers, threatening their livelihoods in many cases.

Groundwater remains the mainstay of social and economic development in the Ganga Alluvial Plateau (GAP) since the dawn of civilization in India. The quaternary sequences that form the upper layer of the GAP are relatively small, accounting for about $30 \%$ of India's reconstructed groundwater resources (unknown, 2006). The increase in groundwater discharge from the GAP has led to significant fluctuations in aquifer pressure such as reduced groundwater leakage and declining groundwater quality (unknown in 1998).Recent studies in three North and East India provinces, such as viz. P.P., Bihar and West Bengal, which cover about $80 \%$ of GAP, have identified 37 community development blocks (groundwater monitoring unit) under the heavily exploited category. Groundwater discharge exceeds annual sources of reproduction (unknown, 2006). The systematic approach is therefore critical to the sustainable development of this precious resource as dependence on groundwater is likely to increase in the future. In this case the first task will be to make a true assessment of groundwater resources and a plan of use in such a way that the full fulfillment of water requirements is met and there is no deforestation or excessive dehydration of the groundwater table. It is necessary to keep the groundwater well in a strong balance over time and water fluctuations should be kept within a certain range during the most favorable seasons of the year. The state of Bihar is part of the plateau in the middle of the Ganga. The Ganges River flows into the region west and east. The area crossing north of the Ganga River is a flat plateau with a regional slope to the south at an altitude of $887 \mathrm{~m}$ above the msl to $34 \mathrm{~m}$ above the msl. The area south of the Ganga River has a regional slope to the north. The southern boundary of the state is marked by the presence of high-rise buildings on the plains of Chotanakupur which cover the vast expanse of Jharkhand region. The highest point seen in this section is $637 \mathrm{~m}$ above the msl in the Kaimur region. About $33 \%$ of the state area south of the Ganga River is covered by deposits used to call the marpinal alluvial glands. Bihar becomes the most important state for enforcing agricultural production in the country. Groundwater is the main source of agricultural agriculture in the country. In view of the above, it is necessary to estimate groundwater replenishment and to generate information that can be used in the planning of extinction by government agencies. The state's sub-water resources are used extensively for agricultural development and their restricted exploitation is limited. There are many 
methods proposed by various researchers to measure groundwater discharge. Due to the complex and complete need for data, it is difficult to use many of them. Keeping simplicity of methodology and availability of information in view the present study has been undertaken to estimate the ground water recharge by water budget method in conjunction with water table fluctuation method with the following objectives:

To estimate the annual ground water recharge using water budget method in conjunction with water table fluctuation method for Munger district.

To develop irrigation plan for utilization of surplus of ground water potential.

The method used to measure groundwater is based on the water budget process as well as the flexibility of the water table and the recommendation of the groundwater committee (GEC-1997). The basic principle followed in this approach is to re-evaluate the annual revenue from rainfall and other sources, including irrigation, water bodies and rehabilitation.

On the basis of annual water production, we must develop an irrigation system for the use of groundwater and calculate the need for additional savings for irrigation systems.

\section{Materials and Methods}

\section{Study Area}

The region is located in the southern part of Bihar province with the city's Munger as its headquarters on southern bank of the Ganga River. The region has an area of $1419.7 \mathrm{sq} \mathrm{km}$ accounting for $3.3 \%$ of the state of Bihar. Between $24^{\circ} 59^{\prime} \mathrm{N}$ to $25^{\circ} 30^{\prime}$ to $85^{\circ} 16^{\prime}$ to $86^{\circ} 42^{\prime} \mathrm{E}$ length. The region is bounded on the north by Kaboli, on the west by the provinces of Lakhisarai and Begusarai, on the east by
Bhagalpur, and on the south by the provinces of Banks and Jamui. The region is divided into three phases and nine developmental themes. There are 903 villages in the district with a population of about 1359054.

\section{Irrigation Practices}

The agricultural activity is by and large confined to the traditional Kharif cultivation due to lack of adequate irrigation system. The principal crops of the district are Paddy, Wheat and Lentils. As per the statistics of the year 2004-2005 (Govt. of Bihar) the gross irrigated area is about 39983 ha.

The cultivable area of district is 64691 ha where 26623 ha is irrigated by deep and shallow tube wells and 13316 ha by canals. Conjunctive use of surface and ground waters can bring the desired development in this water scarce district.

\section{Rainfall and Climate}

The average annual rainfall of the district is $1231 \mathrm{~mm}$ and about $80 \%$ of the rainfall is received during June to September by southwest monsoon. The climate of the district represents a transition between dry and extreme climate of northern India and the warm and humid of West Bengal. There are three distinct seasons in a year. The winter starts from November and last till end February. The summer starts by March end and lasts through May to mid June and the monsoon sets in thereafter which continues till September. In the summer, temperature rise up to $42^{\circ} \mathrm{C}$, while in winter it dips down $2^{\circ} \mathrm{C}$.

\section{Soils}

The Munger district consists mainly of Entisols and Alfisols type of soils under different lithological and pedogenic conditions. Younger alluvial soil of entisols group of soil is restricted on either side of 
river Ganga, mainly on northern and southern Ganga plain. It is deficient in nitrogen, phosphoric acid and humus.

Texturally these soils are sandy to loamy sand and $\mathrm{pH}$ value being on the alkaline side, it occurs mainly in diara area.

Older alluvial soils of alfisols group of soil are developed mainly in the marginal area along northern border of hard rock terrain i.e. south of Ganga.

Red sandy soil of alfisols group of soils occurs in major part of district especially in central part of the district. It has poor fertility and is suitable for high land crop.

\section{Groundwater Recharge}

The methodology used for groundwater recharge is water budget method and water table fluctuation method. The water budget method for recharge of ground water is given by the continuity equation which is expressed as,

Inflow $=$ outflow + change in storage

Schicht and Walton(1961) used this approach to estimate the groundwater recharge, using this equation they derived an expression.

$\mathrm{R}+$ Qon $=\mathrm{Ap} \times \mathrm{ET}+\mathrm{PG}+$ Qoff + Qbf $+\Delta \mathrm{S} \ldots$ (1)

where,

$\mathrm{R}=$ Total ground water recharge .

Qon $=$ Ground water flows on to the basin .

Ap $=$ Area of different grown crops in study area

$\mathrm{ET}=$ Evapotranspiration
$\mathrm{PG}=$ Ground water draft

Qoff $=$ Ground water flows off the basin .

Qbf $=$ Base flow.

$\Delta \mathrm{S}=$ Change in ground water storage

Where,

$\Delta \mathrm{S}=\Delta \mathrm{h} . \mathrm{Sy} . \mathrm{A} \ldots(2)$

Combining equation 1 and 2 , We get,

$\mathrm{R}+\mathrm{Q}_{\mathrm{on}}=\mathrm{A}_{\mathrm{p}} \cdot \mathrm{ET}+\mathrm{PG}+\mathrm{Q}_{\mathrm{off}}+\mathrm{Q}_{\mathrm{bf}}+\Delta \mathrm{h} \cdot \mathrm{S}_{\mathrm{y}} \cdot \mathrm{A}$

Due to unavailability of data on G.W. inflow and outflow into and out of the basin the values of $Q_{\text {on }}$ and $Q_{\text {off }}$ is taken to be equal as suggested by Patra (2011). Considering the above assumptions the equation becomes.

$\mathrm{R}=\mathrm{Ap} . \mathrm{ET}+\mathrm{PG}+\mathrm{Qbf}+\Delta \mathrm{h} . \mathrm{Sy} \cdot \mathrm{A} \ldots .(3)$

Where,

$\Delta \mathrm{h}=$ Water table fluctuation.

Sy $=$ Specific yield .

$\mathrm{A}=\mathrm{It}$ is the area of assessment.

Here $\mathrm{R}$ is the ground water recharge due to the several components.

So,

$\mathrm{R}=\mathrm{Rrf}+\mathrm{Rgw}+\mathrm{Rwc}+\mathrm{Rt}+\mathrm{Rc}$

Where,

$\operatorname{Rrf}=$ Recharge due to rainfall .

$\mathrm{Rgw}=$ Recharge due to irrigation return flow .

Rwc $=$ Recharge due to water conservation structures. 
$\mathrm{Rt}=$ Recharge due to ponds.

$\mathrm{Rc}=$ Recharge from canal system.

So, equation (3) can be written as;

$\mathrm{Rrf}+\mathrm{Rgw}+\mathrm{Rwc}+\mathrm{Rt}+\mathrm{Rc}=\mathrm{Ap} \times \mathrm{ET}+\mathrm{PG}+$ $\mathrm{Qbf}+\Delta \mathrm{h}$. Sy.A...(4)

The wet season (from June to September) during which the water table rises due to rainfall is followed by dry season (other than June to September) in which water table drops mainly due to the G.W. pumping. Therefore the hydrological year can be divided into two distinct seasons, each with a distinct water level rise or fall. Applying equation (4) for the wet season (monsoon season).

The value of specific yield for monsoon and non- monsoon season is same as recommended by GEC-97. Hence the specific yield calculated for the monsoon season can be used for non- monsoon season also.

The hydrological recharge is given by

$\mathrm{R}=\mathrm{A}_{\mathrm{p}} \times\left(\mathrm{ET}^{\mathrm{dry}}+\mathrm{ET}^{\mathrm{wet}}\right)+\mathrm{PG}^{\mathrm{dry}}+\mathrm{PG}^{\text {wet }}+\mathrm{Q}_{\mathrm{bf}}{ }^{\text {wet }}+$ $\mathrm{Q}_{\mathrm{bf}}{ }^{\mathrm{dry}}+\Delta \mathrm{h} . \mathrm{S}_{\mathrm{y}} \cdot \mathrm{A} \ldots \ldots .(6)$

\section{Calculation of physical quantities involved in the above equations.}

\section{Water table fluctuation}

The data of pre and post monsoon water level of Munger district for eleven years (20072017) where collected from Central Ground Water Board and based upon this water table fluctuation was calculated. The long term water table fluctuation in Munger district varies from 0.2 to $3 \mathrm{~m}$ with an average value of $1.7 \mathrm{~m}$. the data shows that water table fluctuation was lowest in the year 2017 and highest in the year 2015. Rainfall recharge in monsoon season $\left(\mathrm{R}_{\mathrm{rf}}{ }^{\text {wet }}\right)-\mathrm{R}_{\mathrm{rf}}{ }^{\text {wet }}$ is the ground water recharge in monsoon season from rainfall. It is calculated by rainfall infiltration method or from rainfall infiltration factor which is given as.

$\mathrm{R}_{\mathrm{rf}}{ }^{\text {wet }}=\mathrm{f} \times \mathrm{A} \times$ normal rainfall in monsoon season....(7)

$=\mathrm{f} \times \mathrm{A} \times \mathrm{R}_{\mathrm{rf}}{ }^{\text {wet }}$ (normal).

Where, $\mathrm{f}^{\prime}$ is rainfall infiltration factor (for Indo-Gangetic and Inland alluvial area, $\mathrm{f}^{\prime}$ varies from 0.15 to 0.22 as norms given by GEC-1997) and A is the area of computation of recharge. The same recharge factor may be used for non-monsoon rainfall recharge, with the condition that the recharge due to nonmonsoon rainfall may be taken to be zero, if the normal rainfall during the non-monsoon season is less than $10 \%$ of normal annual rainfall.

The normal monsoon rainfall (June to September) of Munger districts were calculated from the monthly rainfall data, which is $886 \mathrm{~mm}$ respectively and the nonmonsoon normal rainfall for Munger is 176 $\mathrm{mm}$. And the average annual rainfall is 1062 $\mathrm{mm}$. The average rainfall of the district is $1231 \mathrm{~mm}$ and about $80 \%$ of the rainfall is received

\section{Ground water recharge from groundwater irrigation $\left(\mathbf{R}_{\mathrm{gw}}{ }^{\mathrm{wet}}\right)$}

$\mathrm{R}_{\mathrm{gw}}{ }^{\text {wet }}$ is ground water recharge from groundwater irrigation in monsoon season. Recharge from return flow from groundwater irrigation of Munger district during monsoon season 3384.9 ha- $\mathrm{m}$, which is $30 \%$ of the ground water draft for paddy area and 35\% for non-paddy areas will be taken as per the recommendation of GEC-1997. 


\section{Groundwater recharge from conservation structures $\left(\mathbf{R}_{\mathrm{wc}}{ }^{\mathrm{wet}}\right)$}

$\mathrm{R}_{\mathrm{wc}}{ }^{\text {wet }}$ is groundwater recharge from water conservation structures in monsoon season.

\section{Groundwater recharge from ponds $\left(\mathbf{R}_{t}{ }^{\text {we } t}\right)$}

$\mathrm{R}_{\mathrm{t}}{ }^{\text {wet }}$ is groundwater recharge in monsoon season by ponds and tanks. Under the norms of GEC-1997, it is taken $1.4 \mathrm{~mm} /$ day for the period in which the pond has water. So,

$\mathrm{R}_{\mathrm{t}}{ }^{\text {wet }}=$ pond area $\times 1.4(\mathrm{~mm} /$ day $) \times$ (no.of days)

Assuming, number of days of water storage in monsoon season as 120 days, number of days of water storage in non- monsoon season as 245 days and recharge from ponds of each district is calculated assuming that water is added into ponds only during the four months (June to September). The area of ponds were 3163 ha $\mathrm{m}$ for Munger district.

\section{Ground water recharge from canal system $\left(\mathbf{R}_{\mathbf{c}}\right)$}

The annual running days of this canal is obtained from the Irrigation Department of Govt. of Bihar, which is 120 days for nonmonsoon season and 160 days for monsoon season.

The wetted area for Munger district is taken from the Central Ground Water board Ministry of Water Resources (Govt. of India) Mid- Eastern Region Patna which is 133.16 ha for Munger districts.

Recharge from canal is calculated from the guidelines given by CGWB (CWREC, 1997). For unlined canals in normal types of soil, with some clay content along with sand, 15 to 20 ha- $\mathrm{m} /$ day $/ 10^{6} \mathrm{~m}^{2}$ of wetted area of the canal is taken.

\section{Ground water draft (PG $\left.{ }^{\text {wet }}\right)$}

$\mathrm{PG}^{\text {wet }}$ is the amount of ground water extracted from the ground water resources with the help of pumping unit. The gross ground water draft includes the ground water extraction from all existing ground water structures. The groundwater draft or ground water abstraction can be calculated by the no. of wells of different types multiplied by unit draft. The Central Ground Water Board has carried out hydro geological survey and exploration in the district. Under exploration programme a total of 17 nos. of wells have been drilled, where 11 wells are exploratory and 06 are observation wells. Ground water resources of the district have been estimated (GEC-1997, norm) in the year 2009. The estimation has highlighted the stage of ground water development as $33.3 \%$ in the district.

The monsoon season ground water draft is calculated on the basis of the number of irrigation requirement and the depth of water applied to the main crops grown in kharif season. Some of the kharif crops which grow in the study area are Paddy, Maize, Moong and Urd. Number of irrigation applied and the depth of water irrigation structures applied for kharif crops is listed in table (3.3).

\section{Evapotranspiration}

Evapotranspiration is also known as crop water need. It is defined as the depth (or amount) of water needed to meet the water loss through evapotranspiration. In other words, it is the amount of water needed by the various crops to grow optimally. $\mathrm{ET}^{\text {wet }}$ is the evapotranspiration in the monsoon season as well $\mathrm{ET}^{\mathrm{dry}}$ is the evapotranspiration occurring from the crops in non- monsoon season. ET will be calculated as suggested by Subramanya, (2008)

$\mathrm{ET}=\mathrm{K}_{\mathrm{c}} \times \mathrm{ET}_{0} \ldots(8)$ 
Where,

ET is evapotranspiration,

$\mathrm{ET}_{0}$ is reference evapotranspiration,

$\mathrm{K}_{\mathrm{c}}$ is crop coefficient.

An aquifer is a groundwater-saturated layer that provides enough water for a well to use. Groundwater is water within the open space between soil, sand, and gravel and within fractures in rocks. The infiltration of water into the surface of the water table is called groundwater recharge, and the discharge from the aquifer is called groundwater discharge. Groundwater flow is predominant in the recharging area. Conversely, there is a major groundwater flow in an outlet area. The patterns of groundwater flow to the first discharge areas from the recharge form the groundwater flow systems that form the framework for understanding the recharge processes.

Dependence on groundwater resources has increased tremendously in recent years due to variations in monsoon and scarcity of surface water in many parts of India, especially in arid and semi-arid regions. The availability of credit from financial institutions for the sinking of tube wells and the provision of subsidized / free electricity to pump in many states have increased groundwater augmentation. On the other hand, rapid urbanization and land use changes have greatly reduced the rate of infiltration into the soil and reduced the natural recharging of water bodies by rainfall. All of the above factors helped to reduce the water table, as many wells and tube wells previously drilled previously yielded adequate yields, with their yields now declining and eventually drying up. The situation is most dangerous when the yield of drilled wells and shallow tube wells decreases significantly or dries up.

The drinking water crisis prevailing in most of the villages during the summer is causing serious health hazards to the rural people and causing huge livestock loss due to the need for drinking water and fodder.

Table.1 The Average water table fluctuation ( $\Delta \mathrm{h})$ Munger Bihar (2007- 2017)

\begin{tabular}{|c|c|c|}
\hline S.N. & Year & $\Delta \mathbf{h}(\mathbf{m})$ \\
\hline 1 & 2007 & 1.4 \\
\hline 2 & 2008 & 1.5 \\
\hline 3 & 2009 & 0.6 \\
\hline 4 & 2010 & 1.7 \\
\hline 5 & 2011 & 2.1 \\
\hline 6 & 2012 & 2.6 \\
\hline 7 & 2013 & 2.5 \\
\hline 8 & 2014 & 2.2 \\
\hline 9 & 2015 & 3 \\
\hline 10 & 2016 & 1.5 \\
\hline 11 & 2017 & 0.2 \\
\hline Average & & $\mathbf{1 . 7}$ \\
\hline
\end{tabular}


Table.2 Annual normal rainfall of Munger districts

\begin{tabular}{|c|c|c|c|c|}
\hline S.No & Districts & $\begin{array}{c}\text { Normal Monsoon } \\
\text { rainfall }(\mathbf{m m})\end{array}$ & $\begin{array}{c}\text { Normal Non-monsoon } \\
\text { rainfall }(\mathbf{m m})\end{array}$ & $\begin{array}{c}\text { Annual } \\
\text { rainfall }(\mathbf{m m})\end{array}$ \\
\hline 1 & Munger & 886 & 176 & 1231 \\
\hline
\end{tabular}

Table.3 Number of irrigation and depth of irrigation applied to crops in Munger district, Bihar (National Compilation on Dynamic Ground Water Resources of India, 2017)

\begin{tabular}{|c|c|c|c|c|}
\hline S.No & Crops & Cropping area (ha) & $\begin{array}{c}\text { No. of irrigation } \\
\text { required }\end{array}$ & $\begin{array}{c}\text { Depth of water applied } \\
\text { (cm) }\end{array}$ \\
\hline 1 & Paddy & 3066 & 4 & 30 \\
\hline 2 & Maize & 400 & 2 & 12 \\
\hline 3 & Moong & 170 & 2 & 9 \\
\hline 4 & Urad & 200 & 2 & 9 \\
\hline
\end{tabular}

Fig.1 Location map of study area

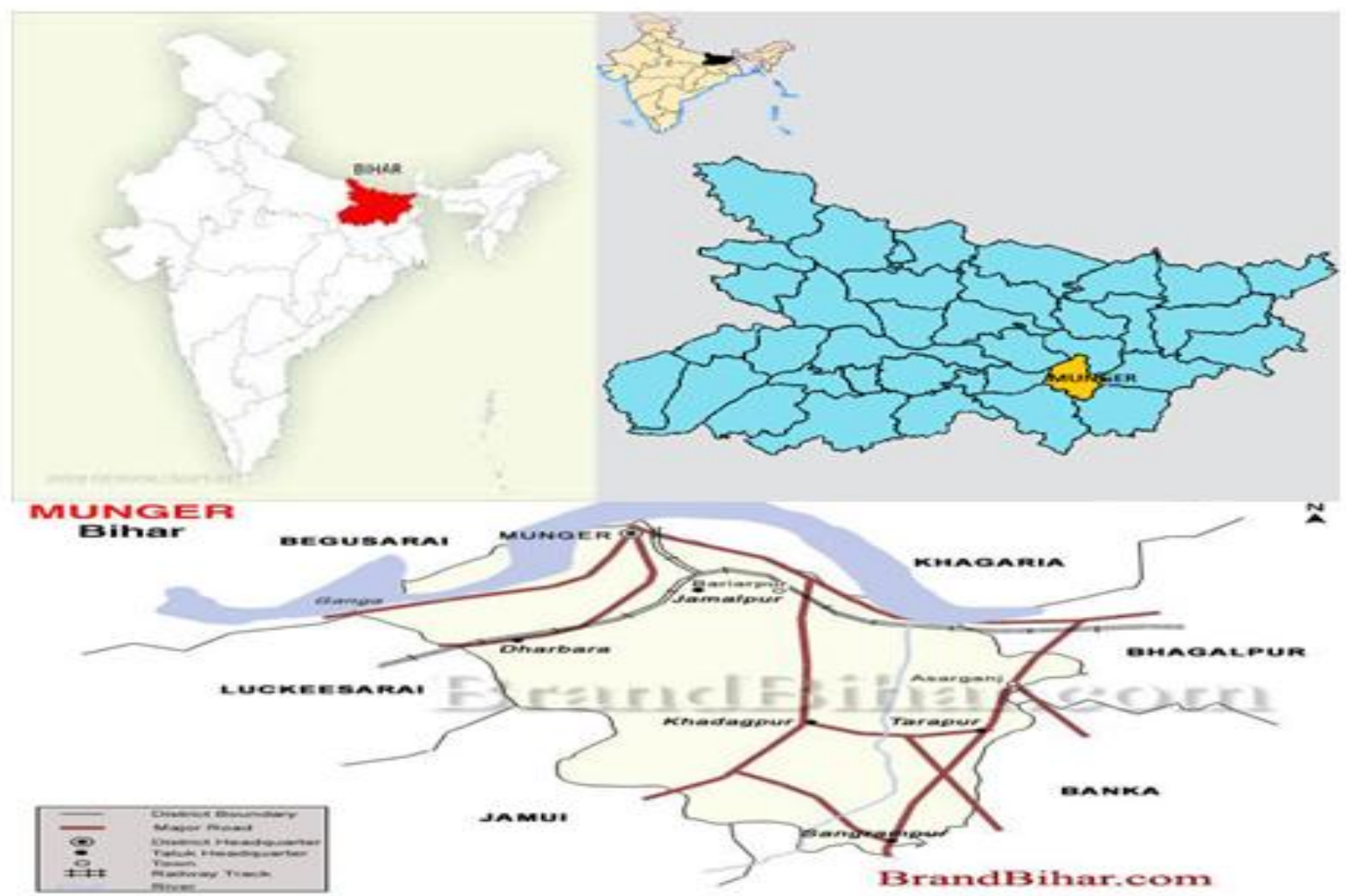


Fig.2

$$
\begin{aligned}
& \mathbf{R}_{\mathrm{rf}}{ }^{\text {wet }}+\quad \mathbf{R}_{\mathrm{gw}}{ }^{\text {wet }}+\mathbf{R}_{\mathrm{wc}}{ }^{\text {wet }}+\mathbf{R}_{\mathrm{t}}{ }^{\text {wet }}+=\mathrm{A}_{\mathrm{p}} \times \mathrm{ET}^{\text {wet }}+\mathrm{PG}^{\text {wet }}+\mathbf{Q}_{\mathrm{bf}}{ }^{\text {wet }}+\Delta \mathbf{h} \cdot \mathrm{S}_{\mathrm{y}} \cdot \mathrm{A}
\end{aligned}
$$

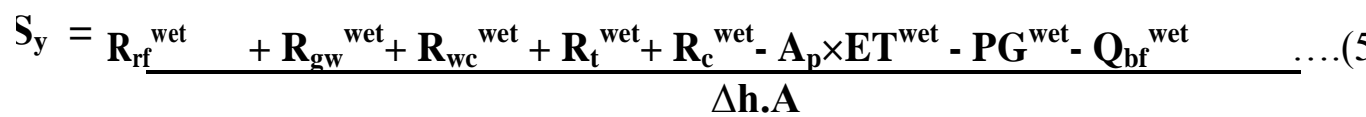

Being a source of groundwater recharge; Its proper and economic development on a sustainable basis requires its realistic assessment. Groundwater has emerged as an important source for meeting the water needs of various sectors, including major consumers of water such as irrigation, domestic and industrial. Sustainable development of groundwater resources requires accurate quantitative assessment based on reasonably valid scientific principles.

There is an urgent need to review the annual recharge estimate and prepare information that can be linked to future demand in order to calculate the full value of groundwater fluctuations and groundwater resources. With this in mind the study was carried out to assess the annual groundwater recharge of Munger district on the basis of GEC-97 regulations. Water level fluctuation techniques and other empirical rules of GCE-97 were used to assess the groundwater level in Munger district. The phase of groundwater development was developed and the assessment units were classified based on groundwater development and long-term water level trend.

\section{Based on the analysis of data following conclusions can be drawn}

During the period of 2007 to 2017, the water table fluctuation of in Munger district varies from 0.2 to $3 \mathrm{~m}$ with an average value of 1.7 $\mathrm{m}$.
Recharge from rainfall in monsoon season for Munger district it is $18867.8 \mathrm{ha} \mathrm{m}$.

Ground water draft in monsoon and nonmonsoon season for Munger district were 1001.1 ha $\mathrm{m}$ and 7968 ha $\mathrm{m}$ respectively.

Annual ground water draft for Munger district it is 8969 ha $\mathrm{m}$.

Recharge from canal in monsoon and nonmonsoon season for the Munger district it were found 42.6 ha $\mathrm{m}$ and 31.96 ha $\mathrm{m}$ for the respective seasons. Recharge from ponds in monsoon and non- monsoon for Munger district were found 531.38 ha $\mathrm{m} \mathrm{ha} \mathrm{m}$ and 1048.9 ha $\mathrm{m}$.

Crop water utilization in Munger district in monsoon is 4240.1 ha $\mathrm{m}$ and 3146.74 ha $\mathrm{m}$ in non-monsoon.

The calculated value of specific yield for 0.10 for Munger district.

Total annual ground water recharge were 37434.63 ha $\mathrm{m}$ for Munger district.

Natural discharge during non-monsoon season for Munger district were found 1974 ha m.

Net ground water availability for Munger district 30907 ha- m. Existing ground water draft for domestic and industrial water supply were 2046 ha $\mathrm{m}$ for Munger district. 
Existing gross ground water draft for all uses were 8968 ha $\mathrm{m}$ for Munger district.

The net ground water availability for future irrigation development were 21097 ha $\mathrm{m}$ for Munger district.

The Stage of ground water development for Munger district have been found to be $33.3 \%$, signifying that the district fall under safe category and have ample scope for further development of the ground water in the district. To bring the ground water development stage up to $60 \%$ in Munger district about 8252 ha $\mathrm{m}$, ground water can further be exploited.

\section{References}

Aadhunik Kissan Diary, (2013). Rajendra Agricultural University, Pusa, Samastipur. 32pp.

Abu-Taleb, M. F. (2003). Recharge of ground water through multi stage reservoir in basin. Environmental Geology. 44(4): 60-65.

Allen, R. G., L. S. Pereria, D. Raes, and Smith, M. (1998).Crop evapotranspiration. Guidelines for computing crop water requirements. FAO Irrig. and Drain., Paper No. 56. Rome, Italy.

Anonymous, (2007). Report of the expert group on "Groundwater management and ownership" submitted to Planning Commission, September 2007. Government of India, Planning Commission, Yojana Bhavan, Parliamentary Street, New Delhi.61 pages.

Anonymous,(2006). Dynamic ground water resources of India as on March 2004.New Delhi Ministry of Water Resources, Government of India. $\mathrm{pp}(187)$.

Anonymous, (2011). Bihar Through Figures
Directorate of Economics and statistics, Bihar, Patna. B.Tech. Thesis, C.A.E., Pusa.

Brown, R. H. (1972). Ground water studiesAn introduction guide to research and practice. JournalofHydrology.7: 3-6.

Chatterjee, R. and Purohit, R. R. (2009).Estimation of replenishable ground water resources of India and their status of utilization.CurrentScience.96 (12): 1581-1591.

Chatterjee, R., Gupta, B. K., Mohiddin, S. K., Singh, P. N., Shekhar, S. and Purohit, R. (2009). Dynamic ground water resource of national capital territory, Delhi assessment, development and management options.EnvironmentalEarth-Sciences.59(3):669-686.Food and Agriculture Organisation of The United Nations, Rome, 20 pp.

Ground water resource estimation methodology (1997). Report of the Ground Water Resource Estimation Committee, Central Ground Water Board Ministry of Water Resources (Govt. of India). New Delhi, June 1997.

Gupta, A., Sarangi, A. and Singh, D. K. (2017). Estimation of crop coefficients and water productivity of mustard (Brassica juncea) under semi-arid conditions. Current Science. 113 (2), $1-9$

Jha, B. C. and Jha, J. (1990). Studies on ground water recharge through cavity well. B.Tech. Thesis, C.A.E., Pusa.

Kaushal, M. P, Singh, P. and Sondhu, S. K. (1997). Ground water potential of upper Bari Doab Canal tract of Panjab.J. Res. Punjab Agric. Univ. 34(3): 328-336.

Kumar, C. P. (1989). Assessment of ground water potential. Proceedings International Seminar on Development and Management of Ground Water Resources. University of Roorkee. 
Lee, C. H., Chen, W. P. and Lee, R. H. (2006). Estimation of groundwater recharge using water balance coupled with baseflow-record estimation and stablebase-flow analysis. Environ Geol. 51: 73-82.

Mall, R. K., Gupta, A., Singh, R., Singh, R. S. and Rathore, L. S. (2006). Water resources and climatic change and Indian prospective.CurrentScience.90(12):1610

Melati, M. D., Fan, F. M. and Gustavo B. Athayde, G. B.(2019) Groundwater recharge study based on hydrological data and hydrological modelling in a South American volcanic aquifer. Jio science 351, 441-450

Mirnia, S. K. and Kowsar, S. A. (2000).Reclamation of sandy desert through flood water spreading.Journal of Agri. Science and Tech. 2(3): 197200.

Murray, J., O Geen, A. T. and Mc Daniel, P. A. (2003). Development of a GIS data base for ground water recharge assessment of the Palouse Basin.Soilscience.168(11); 759-768.

Prasad, Y. S. and Rao, B. V (2018) Groundwater recharge estimation studies in a khondalitic terrain of India. Applied Water Science. 8, 102.

\section{How to cite this article:}

Md Nawid Ashraf, Alex Thomas, Md Tahsin Ashraf and Pankaj Kumar. 2021. Estimation of Groundwater Recharge by Water Budget Method in Conjunction with Water Table Fluctuation Method, Munger district, Bihar. Int.J.Curr.Microbiol.App.Sci. 10(07): 316-326. doi: https://doi.org/10.20546/ijcmas.2021.1007.034 